\title{
Oligoclonal banding in the cerebrospinal fluid of patients with postencephalitic Parkinsonism
}

\author{
A D R I A W I L I A MS, SIDNEY HOUFF, A NDREW LEES, \\ A N D DONALD B. CAL NE \\ From the Experimental Therapeutics Branch, National Institute of Neurological and \\ Communicative Disorders and Stroke, National Institutes of Health, Bethesda, Maryland, USA
}

SUMMARY Two recent sporadic cases of progressive Parkinsonism after encephalitis are described. Both patients had two oligoclonal protein bands in their CSF. These bands were not present in patients with idiopathic Parkinson's disease and might, therefore, be useful for diagnostic purposes, particularly when the history of encephalitis is uncertain.

Cases of Parkinsonism after encephalitis have become a rarity because many of those patients affected during the encephalitis lethargica pandemic of 1919-1926 have died. Of the recently reported patients, most developed Parkinsonism in the acute stage of the encephalitis illness and the extrapyramidal deficits subsequently improved (Fahn, 1977). We now report on two recent cases of progressive Parkinsonism after an encephalitic illness. IgG levels and the presence of oligoclonal banding in the CSF have been investigated in these patients and compared with a group of patients with idiopathic Parkinson's disease.

\section{Case reports}

\section{CASE 1}

A woman from London, now aged 39 years, had been in good health until the age of 19 years when she acutely developed a pyrexial illness associated with delirium and severe daytime sleepiness with nocturnal insomnia. Over a six week period she made a complete recovery. Ten years later she complained of weakness down the left side and was noted to have left sided bradykinesia and rigidity with cogwheel phenomena. Two years later she developed a bilateral resting tremor, and her rigidity and bradykinesia generalised. Later a festinant gait, micrographia, dysarthria, and seborrhoea appeared. Over the last few years she has shown a modest but definite deterioration. She has had no behavioural disturbance, paresis of eye

Address for reprint requests: Dr Adrian Williams, National Institutes of Health, Bldg 10, Rm 3D12, Bethesda, Maryland 20014, USA. Accepted 16 February 1979 movements, oculogyric crises, dementia, or pyramidal tract signs. Treatment with anticholinergics and bromocriptine produced modest benefit but she was unable to tolerate even small doses of levodopa because of violent drug-induced invol untary movements. There was no relevant pas? medical history and no family history of neuro@ $\vec{\infty}$ logical disorder. Investigations including EEG $\mathbb{D} \mathbb{O}$ skull radiographs, haematological and biochemica历 screen (with estimation of serum calcium, coppe 궁 and caeruloplasmin) were normal. The CSF at the time of diagnosis of Parkinsonism showed a pro $\vec{\varphi}$ tein level of $0.2 \mathrm{~g} / 1$ and 5 lymphocytes $/ \mathrm{ml}$.

CASE 2

A woman from Nebraska, now aged 52 years, had been well until the age of 49 years when she woke up one morning feeling as if she had influenza. By that evening she was in a coma which lasted for six days. An EEG at the time showed prominent delta activity, and her CSF contained 150 white cells per $\mathrm{mm}^{3}$, predominantly lymphocytes, with a protein level of $0.73 \mathrm{~g} / 1$ and a normal glucose concentration. As soon as she had recovered from her acute illness it was noted that she had difficulty with walking and breathing, slurred speech, and a mild resting tremor in her legs. She remained stable for two years, and then over six months started having increasing difficulty with her walking, a more prominent tremor, increasing clumsiness with fine motor tasks, and increased difficulty with breathing and swallowing. Examination now revealed a typical Parkinsonism resting tremor in her lower limbs, marked generalised bradykinesis, difficulty with coordination, marked micrographia, 
and the gait of severe Parkinsonism. Palatal myoclonus was present (which had not been present six months previously) at a rate of 140 beats per minute and was in synchrony with a tremor around her jaw and larynx but not synchronous with the tremor in her lower limbs. She took rapid small breaths and consequently suffered from chronic alveolar hypoventilation, although on command she could take deep adequate breaths. Her intellect was intact, and there were no disturbances of eye movement and no cerebellar or pyramidal tract signs. She was treated with 5-hydroxytryptophan in an unsuccessful attempt to help her palatal myoclonus. L-dopa in moderate dosage helped her bradykinesia. There was no relevant past medical history and no family history of neurological disorder. Investigations, including an EEG, haematology and biochemical screen (with estimation of serum calcium, copper, and caeruloplasmin) were normal.

Several other patients developed encephalitis around this time in Nebraska but only one led to Parkinsonism and that was transitory.

\section{Methods}

IMMUNOGLOBULIN STUDY

Cerebrospinal fluid IgG was measured by radioimmunoassay (Mingioli et al., 1978). Oligoclonal banding was detected by agarose gel electrophoresis using the panagel system (Millipore, Inc) (Johnson et al., 1977). The electrophoretic strips were read by an observer who was unaware of the clinical details of the patients.

\section{VIRAL STUDY}

Serum and CSF antibody titres were studied in both cases during the chronic stage of their disease. Titres were measured by microtitre technique to the following viruses: measles and rubella by complement fixation and haemaglutination inhibition; vaccinia by immunadherence, Coxsackie A and $B$, influenza $A$ and $B$ by complement fixation; poliovirus by neutralisation; arbovirus and herpes virus by immunadherence and rabies virus by immunofluorescence (Lennette and Schmidt, 1969).

\section{Results}

Cerebrospinal fluid cell count, protein, and IgG levels in both patients were within the normal range by the time of this study.

Both patients had two definite oligoclonal protein bands in their CSF. Serum electrophoresis did not show any oligoclonal IgG bands.
Six patients with idiopathic Parkinson's disease had a normal IgG and no oligoclonal bands in the CSF.

Serum antibody titres were normal in the two patients with postencephalitic Parkinsonism and in the patients with idiopathic Parkinson's disease. Neither group had detectable CSF antibody to any of the viruses tested.

\section{Discussion}

Both patients developed a progressive form of Parkinsonism after an encephalitic illness. In the first case there was a delay of 10 years, but in the second case Parkinsonism developed in the acute stage and subsequently progressed. This is similar to the pattern shown in the cases of Parkinsonism which followed the epidemic of encephalitis lethargica (von Economo, 1931) but is unlike all the recent cases described in which Parkinsonism developed in the acute or convalescent stage of the illness and later improved (Fahn, 1977). The sleep reversal seen in the first patient was comparable to that seen in many patients with epidemic encephalitis lethargica, and the presence of palatal myoclonus and the respiratory disturbance in the second case was also reminiscent of the disturbances described during this pandemic. However, neither of our patients displayed other features of postencephalitic Parkinsonism, such as disturbance of eye movements, oculogyric crises, or psychiatric abnormalities, and no definite cases of encephalitis lethargica have been described since a few reports appeared in the 1950s (Bickerstaff and Cloake, 1951; Espir and Spalding, 1956).

Influenza A virus antigen has been described in the hypothalamus and midbrain from six patients with Parkinsonism after encephalitis lethargica (Gamboa et al., 1974), and it seems likely that this virus was the cause of the pandemic (Fahn, 1977). The incidence of Parkinsonism in other forms of encephalitis is far less common, although it has been documented after western equine (Mulder et al., 1951). Coxsackie B (Walters, 1960), Japanese B (Richter and Shimojyo, 1961), measles (Meyer, 1943), and possibly polio virus encephalitis (Duvoisin and Yahr, 1965). The mechanism of production of the Parkinsonism is unclear, but in the acute cases it is presumably caused by direct damage by the virus to the substantia nigra or the striatum. The cause of the cell death in cases with delayed onset of Parkinsonism is unknown and could be the result of persistent virus, or secondary to an autoimmune phenomenon.

It is, therefore, of some interest that in our 
patients oligoclonal bands were found in the CSF. These bands are usually present in diseases known to be caused by chronic viral infection such as subacute sclerosing panencephalitis or a presumptive viral infection such as multiple sclerosis (Link and Muller, 1971); in the former disease they are largely due to anti-measles antibody (Noorby and Vandvik, 1975) whereas in multiple sclerosis their origin is obscure. The bands are usually caused by an IgG antibody and hence are regarded as evidence of a humoral immune reaction. Unfortunately, the antigen responsible for them in our patients could not be identified; it could be related either to an infective agent, or to a component of CNS tissue.

It appears that sporadic cases of Parkinsonism after encephalitis are still occurring and in rare cases are progressive. Based on our findings, looking for oligoclonal banding in the CSF might be of some help, both for diagnosis and for epidemiological studies, in confirming that a case of Parkinsonism is related to an encephalitic illness, particularly when the history of encephalitis is uncertain.

We are grateful to $\mathrm{Dr}$ G. M. Stern for permission to publish details of case 1 , and Ms Pamela Barnicoat for typing the manuscript. AL is a Parkinson's Disease Society Research Fellow.

\section{References}

Bickerstaff, E. R., and Cloake, P. C. P. (1951). Mesencephalitis and rhombencephalitis. British Medical Journal, 2, 77-81.

Duvoisin, R. C., and Yahr, M. D. (1965). Encephalitis and parkinsonism. Archives of Neurology (Chicago), 12, 227-239.

Espir, M. L. E., and Spalding, J. M. K. (1956). Three recent cases of encephalitis lethargica. British Medical Journal, 1, 1141-1144.

Fahn, S. (1977). Secondary Parkinsonism. In Scientific Approaches to Clinical Neurology, vol. 2, pp. 11591189. Edited by E. S. Goldensohn and S. H. Appel. Lea and Febiger: Philadelphia.
Gamboa, E. T., Wolf, A., Yahr, M. D., Harter, D. H., Duffy, P. E., Barden, H., and Hsu, K. C. (1974). Influenza virus antigen in postencephalitic parkinsonism brain: detection by immunofluorescence. Archives of Neurology (Chicago), 31, 228-232.

Johnson, K. P., Arrigo, S. C., Nelson, B. J., and Ginsberg, A. (1977). Agarose electrophoresis of cerebrospinal fluid in multiple sclerosis: a simplified method for demonstrating cerebrospinal fluid oligoclonal immunoglobulin bands. Neurology (Minneapolis), 27, 273-277.

Lennette, E. H., and Schmidt, N. J. (1969). Diagnostic Procedures: for Viral and Rickettsial Infections. Fourth edition. American Public Health Association: Washington.

Link, H., and Muller, R. (1971). Immunoglobulins in multiple sclerosis and infections of the nervous system. Archives of Neurology (Chicago), 25, 236344.

Meyer, B. (1943). Encephalitis after measles with severe parkinsonian rigidity: recovery. British Medical Journal, 1, 508-511.

Mingioli, E. S., Strober, W., Tourtellotte, W. W., N Whitaker, J. N., and McFarlin, D. E. (1978). co Quantitation of IgG, IgA and IgM in the CSF by o radioimmunoassay. Neurology (Minneapolis), 280 991-995.

Mulder, D. W., Parrott, M., and Thaler, M. (1951)त Sequelae of Western equine encephalitis. Neurologs (Minneapolis), 1, 318-327.

Norrby, E., and Vandvik, B. (1975). The relationship between measles virus-specific antibodies an oligoclonal IgG in the cerebrospinal fluid in patients with multiple sclerosis. Neurology (Minneapolis) 25, 493.

Richter, R. W., and Shimojyo, S. (1961). Neurologic sequelae of Japanese B encephalitis. Neurology (Minneapolis), 11, 553-559.

von Economo, C. (1931). Encephalitis Lethargica: its Sequelae and Treatment. Translated by $\mathrm{K}$. $\mathrm{O}$. Newman. Oxford University Press: London.

Walters, J. H. (1960). Postencephalitic parkinson syndrome after meningoencephalitis due to Coxsackie virus group B, type 2. New England Journal of Medicine, 263, 744-747. 